Nilce M. Pereira

\title{
Translational Functions of Book Illustrations, and What Dickens Has to Do with Them
}

\begin{abstract}
This article examines book illustration from the perspective of translation studies - as intersemiotic translation. It is suggested that while illustrations can operate in multiple ways - as clarification, adornment, addition, and so on as translations they should be thought of in terms of two different types of function that they fulfil in the literary work. The main function of illustrations, their primary function, is to render the text from the verbal into the visual medium. Other secondary functions that the pictures may perform will then be dependent on how the primary function has been accomplished; that is, on whether the pictures translated the text in such a way as to clarify it, add to it, or even contradict or deviate from its purposes. The illustrations in three of Dickens's novels will be used to exemplify these points.
\end{abstract}

Keywords: book illustration, Dickens's novels, functions

\section{Book illustration as intersemiotic translation and Charles Dickens}

The idea of book illustration as intersemiotic translation is not a new one in literary or translation studies. Riitta Oittinen $(2000,106)$ points out that there are "many similarities between translation (into words) and illustration (translation into pictures) as forms of interpretation," and, in her analysis of the illustrations in Dryden's version of the Aeneid, Eleanor Winsor Leach $(1982,175)$ suggests that "the art of translation may approach that of illustration, both in its need to convey to the reader a coherent image couched within the understandable contemporary idiom and in its responsibility for preserving fidelity to the text." Intersemiotic translation, or transmutation, was first described by Roman Jakobson (2000) as translation between two different systems of signs, for example, from the verbal into the musical, the photographic, or the pictorial medium - and thus also from a literary text into illustrations. Other theories can also help us understand the compatibility of the media involved. Haroldo de Campos's (1970, 21-38) argument that literary translation is possible only by means of aesthetic 
recreation, ${ }^{1}$ for example, adds new support for consistency between the verbal and the visual media in translation, for it implies a reconstitution of the aesthetic information of the text in similar aesthetic form.

Such notions as these are underpinned by the fact that the activities of translation and illustration are carried out in very similar ways. With respect to the mechanics of book production, both translations and illustrations are produced to satisfy specific editorial demands, and both are strongly influenced by publishers. The publisher is not only responsible for commissioning the relevant professionals but also for deciding on general features of the publication (style, compositional elements, target audience, and so forth), so that, in both cases, he/ she has a say in every aspect of the end product. These similarities can extend to the level of the creation of illustrations, for translators and illustrators make use of the same types of resources in the process of translating or illustrating. Translational procedures such as addition, omission, condensation, and suppression, amongst others (see Delisle et al. 1999), are commonly employed by translators and illustrators. And so are strategies such as foreignization and domestication (see Venuti 1995), to specify but one binary pair, for both translators and illustrators may (by means of cultural references, choice of words/visual elements, and so on) allude (and bring the reader closer) to either the source or target culture, depending on the way they approach the text being translated/illustrated. ${ }^{2}$

Both translation and illustration are metonymic arts. Maria Tymoczko (1999, 41-61) points out that metonymy is inherent to translation because, facing the impossibility of encompassing all textual, literary, and cultural features of a text, translators privilege some aspects to the detriment of others, always having to make choices:

1 Campos applies Max Bense's concepts of documentary information, semantic information, and aesthetic information to an exemplary sentence, "A aranha tece a teia" [The spider weaves the web], and to the first stanza of "Formas do Nu" [Forms of the Nude] by Brazilian poet João Cabral de Melo Neto. He proposes that, as a piece of documentary or semantic information, if the sentence were translated into another language, it could be reorganized in various ways: "The spider produces the web," "The web is made by the spider," "The web is a secretion of the spider," and so on. The opening of the poem (a piece of aesthetic information), however, "A aranha passa a vida/ tecendo cortinados/ com o fio que fia/ de seu cuspe privado" [The spider passes through life/ weaving curtains/ with the thread it threads/ from its private spit], could be translated in no other form but the one in which it was transmitted by the artist (Campos 1970 [1963], 22-23; my translations). He argues that any change in the original sequence of the poem would interfere with its "aesthetic realization," so that it is necessary that the poem be recreated in the other language in aesthetic form as well.

2 In Pereira (2007), I discuss how translational procedures and strategies are used in the illustration of Brazilian translations and adaptations of Alice in Wonderland. 


\begin{abstract}
Translators must make choices, because no perfect homology is possible, not even in synonymy or intralingual paraphrase. Decisions are required in translation, because there is always loss and gain in moving between languages and between cultural discourses, because a translator cannot capture everything, because there are inconsistent demands on the translator, because there are limits on the practicable information load of the target text and so forth. Translators select some elements, some aspects, or some parts of the source text to highlight and preserve; translators prioritize and privilege some parameters and not others; and, thus, translators represent some aspects of the text partially or fully and others not at all in translation. (Tymoczko 1999, 55)
\end{abstract}

Tymoczko quotes Lawrence Venuti, for whom there is no complete or total translation, the translated text being "irredeemably partial in its interpretation" (quoted in Tymoczko 1999, 55), and she concludes that "by definition, therefore, translation [...] is a form of representation in which parts or aspects of the source text come to stand for the whole" (Tymoczko 1999, 55). When applied to illustration, the same principles prove to be true, as a literary text is illustrated never in its integrity, but in parts which are selected by the illustrator according to his/her criteria of what is appropriate or possible to illustrate, and which will represent the totality of the text. Thus, similarly to translators, illustrators, too, face constraints of various types (the publisher, the characteristics of the publication, the medium, and the text itself), and have to make choices.

Illustration can be particularly regarded as a form of translation, though, because, as such, it modifies the experience of reading. In an illustrated work of literature, the text is shown to the reader/viewer through the eyes of the illustrator, who, in turn, will always ground his/her views in a particular interpretation. Joseph Schwarcz points out that "[t]he illustrator, consciously or unconsciously, tastefully or crudely, interprets” (1982, 104; emphasis in original), and Stephen Behrendt $(1997,30)$ adds to this idea by remarking that "the illustrator generally shows us not how a scene or figure appears to its author but rather how it appears to the illustrator, and those two appearances can never be precisely identical." Behrendt also suggests that, by interpreting the text, the illustrator plays an intrusive role in the work: the illustrator "intrudes his or her interpretation into an intellectual and aesthetic transaction that would otherwise involve only the literary author and the reader" (1997, 24; emphasis in original), and, in doing so - and because his/her views are never neutral or unbiased - just like the translator, the illustrator interferes in the reception of the text.

Such ideas will be used here to examine book illustrations from the perspective of translation studies - as intersemiotic translations. Charles Dickens is a significant author in this respect not only because illustrations abound in his works, but also because they were produced over a period of almost thirty years, by various artists, which allows different aspects of the illustration process to 
be observed. Illustrations have always been a part of the universe of Dickens's books. With the exception of Hard Times (1854) and Great Expectations (1860), all his works were originally illustrated, an aspect which he took as seriously - sufficiently enough to be closely involved in it - as the production of the text itself: "he usually retained the illustrated format clearly convinced, despite the difficulties of coordinating text and pictures, of its advantages to himself, his publishers, his illustrators to a lesser extent, and, above all, to his readers" (Cohen 1980, 3). In fact, Dickens's career as a writer coincides with the heyday of illustration and the illustrated novel in England from 1836 to 1870 (Cohen 1980, 3-4). Thus, the study that follows is also broadly exemplary for, and more specifically illustrative of, the classic age of book illustration.

\section{The translational functions of book illustration}

The examination of illustrations as translations should be based on the assumption that, as much as the text, illustrations narrate. The narrative capability of images is obviously expressed by other means than those pertaining to verbal constructions. Being static, images can only simulate the development of action and the passing of time. But precepts such as size, shape, location, thickness of lines, colour, texture, level of saturation, and so on produce tension between the objects in a picture, causing them to be seen dynamically (see Nodelman 1988). These elements can also be organized in such a way that certain objects are given more importance than others (visual weight), or so as to direct the eyes of the reader/ viewer to specific points (directed tension; see Nodelman [1988, 125-157]) - both of which are also ways to simulate action. Allied with typifications and distortions of movements and changes, gestures, symbols, and other conventions, pictures offer enough repetition to create a rhythm for the story and thus do imply events and their progression in time (see Nodelman 1988, 158-221).

I also suggest that the study of illustration as translation should be carried out on the same basis as the study of interlingual translation (translation proper; Jakobson [2000, 114]), both in terms of employing the same theoretical tools to analyse them, and in considering the verbal text as the source text (ST) and the illustrations as the target text (TT). This does not imply the primacy of the text over the illustrations, or any kind of hierarchical ranking of the verbal and visual languages. Rather, it can be legitimized by the coexistence of both media in the same space of the book. In contrast to literary images in a catalogue or hanging on the walls of an art gallery, the illustrations in a book cannot be dissociated from the text. Moreover, in an illustrated book, the pictures are meant to represent the 
text - not the opposite - and the text is always the parameter in terms of which they should be examined: "Criticism of the illustration [...] must deal with images in relation to text; otherwise the critic has no logical grounds for evaluating the creative activity of illustrators" (Hodnett 1986, 1). The pictures exist because the text exists and has to be illustrated.

A distinction should also be made between the concept and the function(s) of illustration. Illustration has been defined in various ways, as illustrations have been seen to fulfil a number of functions in the illustrated book. For J. Hillis Miller (1992, 61), illustrating means "bringing to light"; for Bob Gill and John Lewis (1964, 7), it is "a visual answer to a specific problem"; and for Kurt Weitzmann $(1959,1)$, it is "clarification." Where functions are concerned, Hodnett $(1990,1)$ argues that illustrations have three: "to decorate, to inform, and to interpret"; N. C. Wyeth (quoted in Gannon 1991, 93), proposes that they should add to the text; Behrendt $(1997,28)$ sees them in a more dynamic and open way, as in his opinion they can “alter, expand, contradict, or even ridicule or repudiate" the text; Schwarcz (1982, 14-18) lists congruency, elaboration, extension of the situation, and deviation as functions of illustrations; and Frank Weitenkampf (quoted in Harthan 1981, 8) suggests that illustration "must either elucidate the text or adorn it. It may do both: sometimes it does neither."

At some point, the concept and the function of illustration seem to merge. Miller's affirmation that to illustrate is to bring to light is close to the idea that the function of illustration is to elucidate or to clarify; and if Behrendt gives illustrations roles such as those of contradicting or refuting the text, this is consistent with the argument that they may deviate from what would be expected from them. These notions are certainly based on personal views and (especially in the case of those who are also artists) the way each theorist relates to art. To mention but one example, it is probable that illustrating has the sense of addition for Wyeth because of his idea of how to approach a literary text: "Why take a dramatic episode that is described in every detail and redo it? Instead I create something that will add to the story" (quoted in Gannon 1991, 93; Wyeth's emphasis). In fact, there is nothing wrong with this or any of the other notions mentioned above, except that they may lead to the assumption that the concept and function of illustration will always coincide, that is, that illustrating is always clarifying or the function of illustrations is always to complement the text - the assumption that this study sets out to refute.

I also, finally, suggest that, as translation, illustrations should be thought of in terms of two different types of function that they perform in the illustrated book. The main function of illustrations, their primary function - which would describe the activity of illustrating per se - should be to render the text from the verbal into the visual medium. The specific way(s) in which illustrations operate 
in relation to the text should be regarded as their secondary function(s). In other words: to illustrate is to translate the text from the verbal into the visual medium. Then, other (secondary) functions that the pictures may perform in the particular universe of the book will be variable, conditioned by the way(s) in which the primary function is carried out as a process of aesthetic recreation, which may result in images that relate to the text so as to clarify it, so as to add other pieces of information to it, so as to contradict it, and so forth. The pictures in Dickens's Oliver Twist (Bentley's Miscellany, 1837-1839), illustrated by George Cruikshank; The Old Curiosity Shop (Master Humphrey's Clock, 1840-1841), illustrated by George Cattermole and Hablot Knight Browne (Phiz), as well as by Daniel Maclise and Samuel Williams (one each); and Bleak House (Bradbury and Evans, 18521853), illustrated by Phiz, show these ideas in action.

\section{The illustrations in Oliver Twist, The Old Curiosity Shop, and Bleak House}

In Oliver Twist, George Cruikshank uses closed spaces to represent the main themes dealt with in the book (abuse at the hands of the system, the distance between those in authority and the poor, the philosophies of profit and individualism in Victorian society, and death, amongst others), as is expressed particularly in his portrayal of indoor scenes. An heir of Hogarth's conventions, Cruikshank makes use of emblems such as objects of art and pictures hanging on walls to denote these aspects, as well as other aspects of character and plot (see Cohen 1980, 23-24). But it is especially by means of small rooms, in whose environment the characters are all concentrated (even entrapped and asphyxiated, as Miller [1965, 36-52] would suggest about the text of Oliver Twist), that these motifs are reinforced. Notice, for example, that, except for the tiny lattice window through which Oliver is obliged to pass in the episode of the burglary at the Maylies' (Dickens 2002, 182), and the one through which Monks and Fagin watch Oliver in the little cottage room (282), nearly all of the rooms lack windows. The low ceiling in some illustrations (Fagin's den [65], the kitchen in Mr Sowerberry's house [49; see fig. 1], the place where Monks meets Mr and Mrs Bumble [315], and even Mr Brownlow's sitting room [91]), intensify the feelings of enclosure - a reflection of the suffocation caused by institutional structures and of the conditions in which the characters find themselves stuck, be it a life of crime, self-sacrificing devotion, or the quest for an identity.

These pictures have a dreadful quality, which is emphasized in scenes such as that of Oliver's return to Fagin's hands, when Sikes's shadow is projected onto 




Fig. 1: George Cruikshank, "Oliver plucks up a spirit” (1837).

the wall and ceiling of the den (Dickens 2002, 126), and can also be seen in almost every illustration in the doomed effect created by the cross-hatching technique. Juliet John $(2006,134)$ suggests that Dickens "domesticates the Gothic, bringing it into surreal collision with domestic and realistic settings," which is also evidenced in the pictures. In the plate of Fagin in the condemned cell (Dickens 2002, 444; see fig. 2), for instance, the character's isolation, his gazing into space, and the expression of despair on his face all evoke the heightened emotions and the dramatic impact which characterize the Gothic. In fact, all the characters in Oliver Twist are portrayed in a theatrical way, in exaggerated gestures and unnatural poses - another resemblance to Hogarth in Cruikshank's aesthetics. Notice Oliver kneeling down before the magistrates (Dickens 2002, 20) or the faces of the boys in 


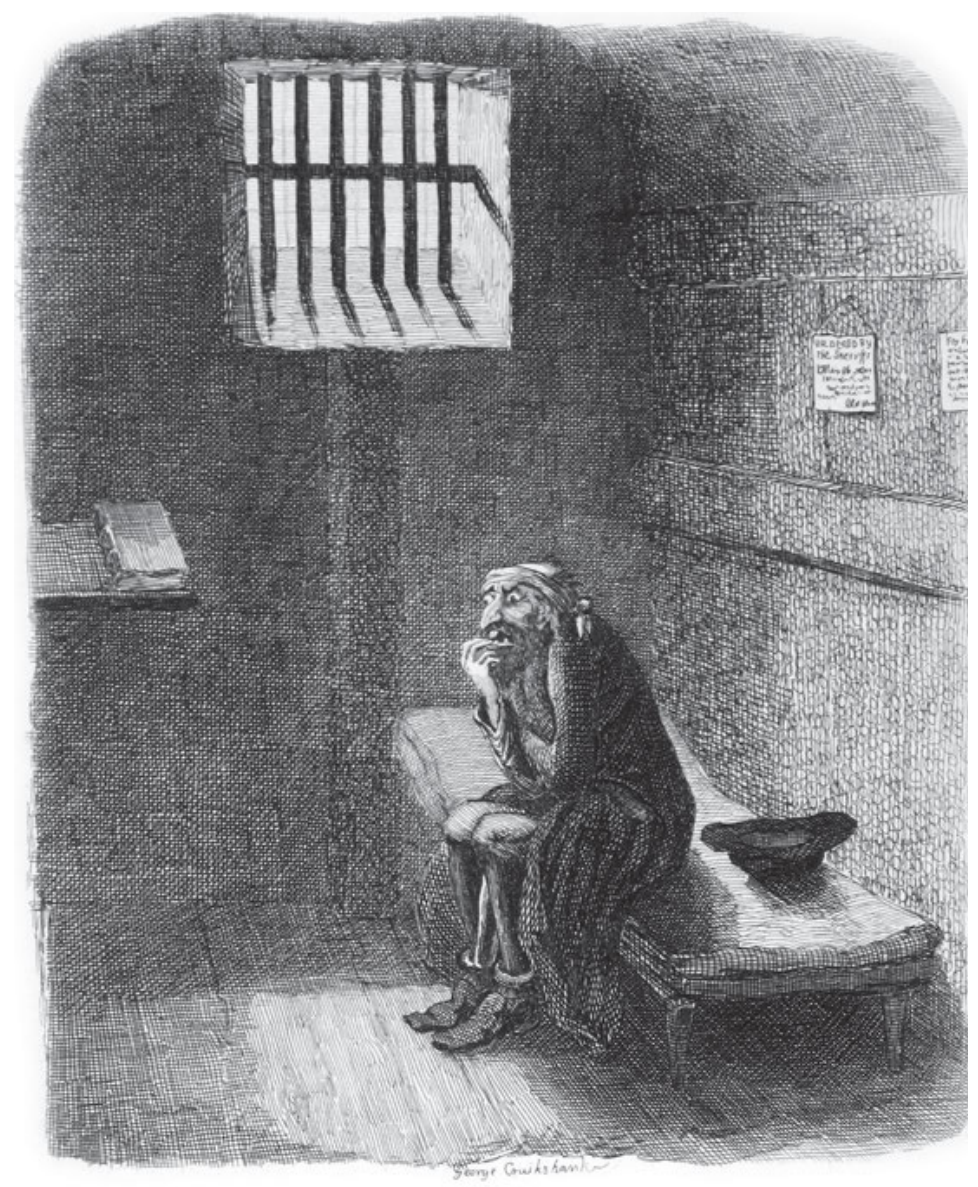

Fig. 2: George Cruikshank, “Fagin in the condemned cell” (1839).

the famous "Oliver asking for more" (16; see fig. 3). Moreover, they are regarded as ill-favoured in appearance. Cohen $(1980,24)$ classifies them as "malproportioned, if not downright unattractive." She mentions Fagin's and Oliver's thinness, Bumble's and Brownlow's plumpness, and Nancy's robustness, among other traits, as making the characters unappealing in general (Cohen 1980, 22). In any case, these elements reiterate the stylized effect of the plates and, combined, give them a grotesque dimension, which is another way to corroborate textual meaning.

In several instances, too, the pictures enter into an ironic relationship with the captions accompanying them. This is the case with the representation of Oliver's recapture by Fagin's gang. In it, the image shows Oliver being grabbed by the 


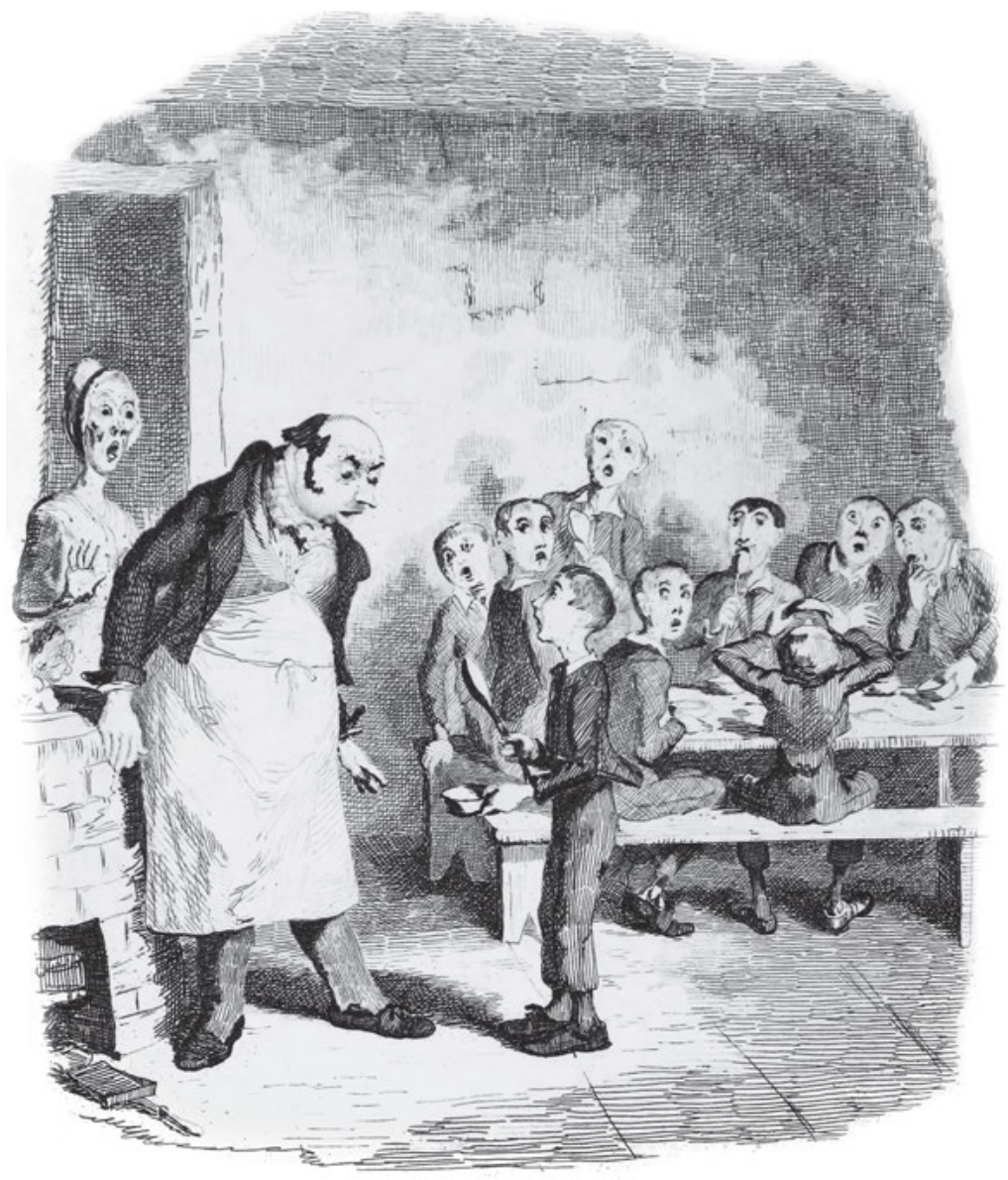

Fig. 3: George Cruikshank, “Oliver asking for more” (1837).

collar by Sikes while the caption informs us: "Oliver claimed by his affectionate friends" (Dickens 2002, 121; see fig. 4). The passage when Oliver first meets Fagin is another example. While the plate portrays Fagin with a trident-like fork in his hand, the caption reads "Oliver introduced to the respectable Old Gentleman" (65). Another example is the drawing "Oliver amazed at the Dodger's mode of 'going to work,"” which shows the pickpocketing of Mr Brownlow's handkerchief (75). Even the picture of the encounter of Mr Bumble and Mrs Corney, "Mr. Bumble and Mrs. Corney taking tea” (188), can be regarded as ironic, as Mr Bumble's clear advances on Mrs Corney and their knowing smiles reveal their romantic interest in each other. In fact, the captions reproduce extracts from the text itself, which 


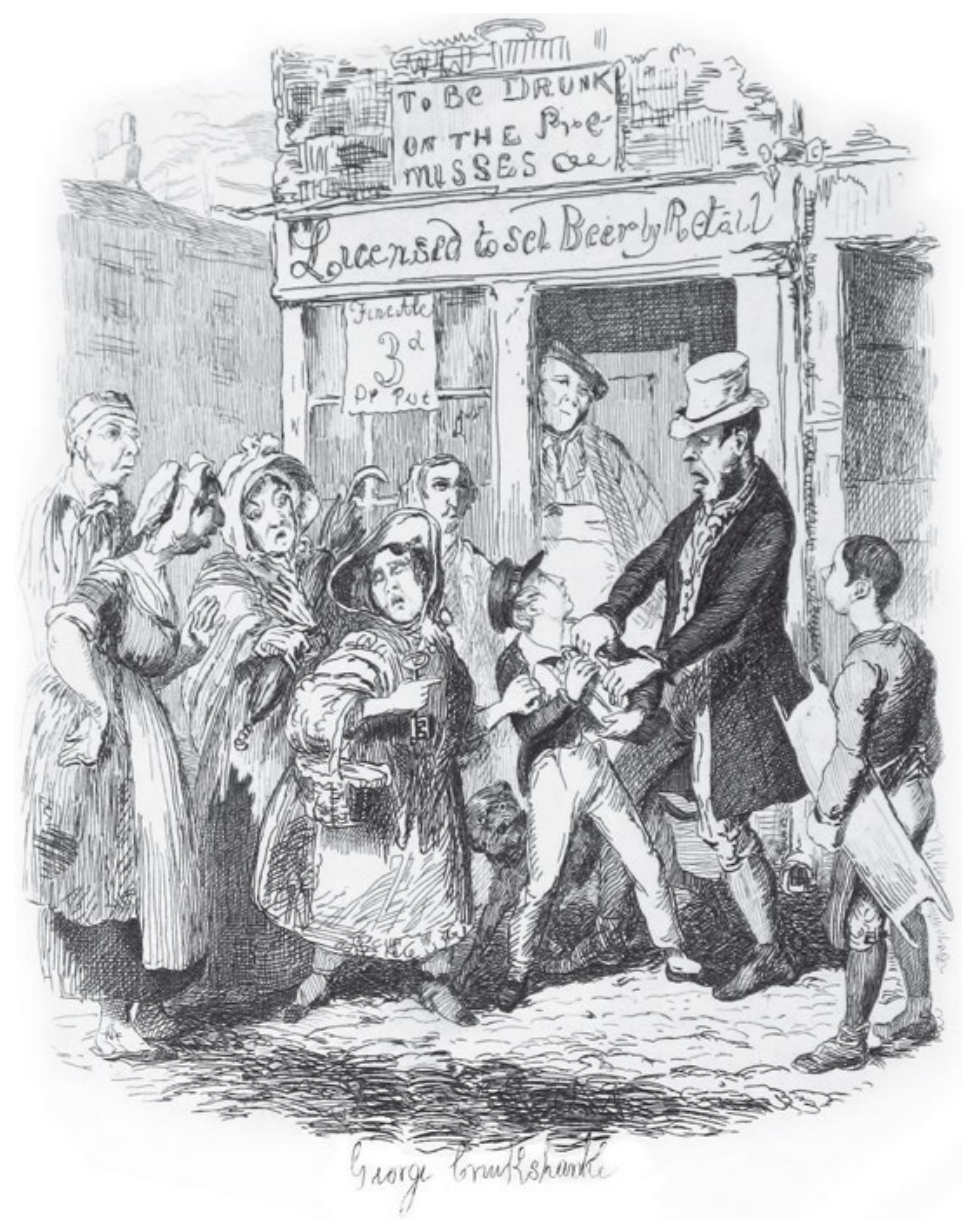

Fig. 4: George Cruikshank, "Oliver claimed by his affectionate friends" (1837).

is ironic per se. By being separated from the text, the sentences lose connection with their textual context and create another context with the pictures against which they are placed. In the text, it is Dickens's style which creates irony. In the visual representations, it is the illustrations: the captions are ironic because the images tell us so.

In The Old Curiosity Shop, however, the illustrators mostly highlight contrasts. Nell's graceful figure and the grotesqueness of her surroundings are especially remarkable, but they can be extended, on the thematic level, to oppositions of good and evil, innocence and craftiness, and so forth. Samuel Williams's plate of Nell asleep in the midst of all kinds of bibelots in the curiosity shop (Dickens 


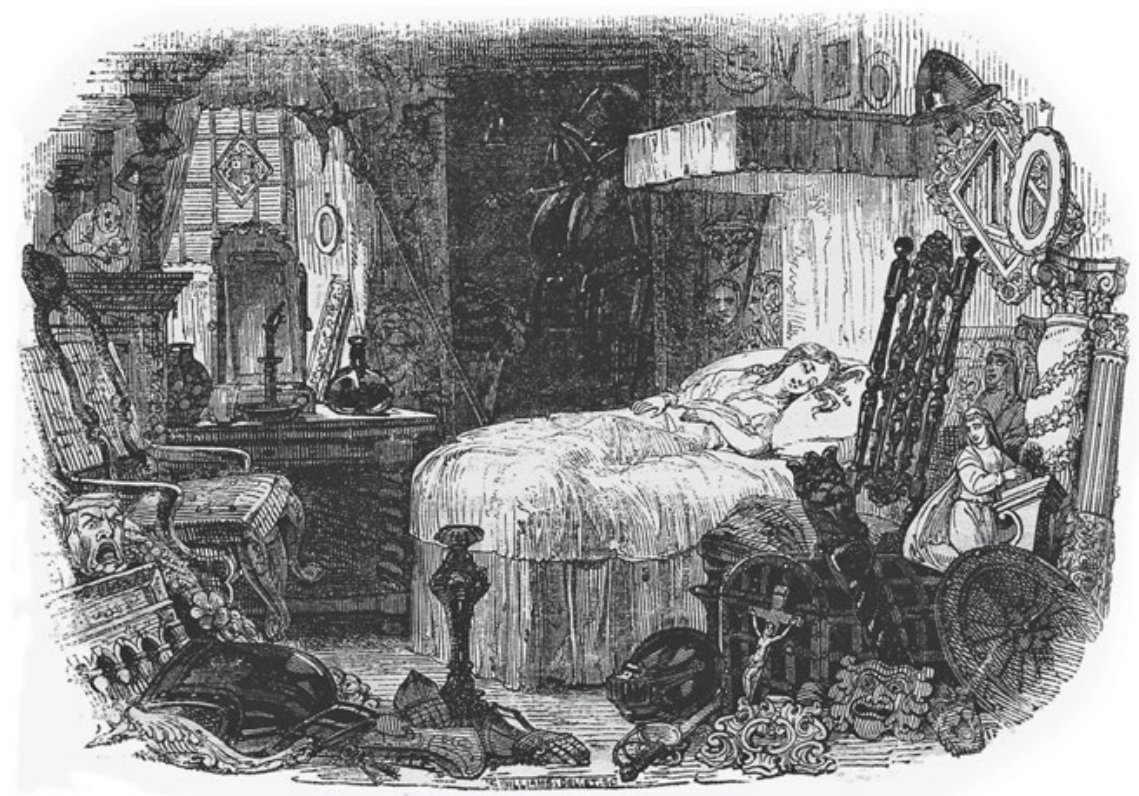

Fig. 5: Samuel Williams, “Nell in bed” (1840).

2008, 19; see fig. 5) is a classic example, but others can be observed throughout the book when she is depicted in sombre decayed settings, in the company of weird characters, or experiencing "the squalid horrors" (Dickens 2008, 352) she had been forced through. The presence of her grandfather, too, imposes a parallel between youth and old age, and there is also the alternation of the images of Nell and of Quilp and his associates. In some pictures, Quilp's deformed figure and ugliness are representative of his evil personality, as exemplified by his devil-like face in Phiz's plate depicting him defying a dog (170). In others, as when Nell hides from Quilp (211), these traits are reinforced by means of symbolic elements, such as the demonic statues on each side of the arch in the old gateway of the town.

Miller $(1965,94)$ suggests that the central axis in The Old Curiosity Shop is the opposition between "the city, the prison of the industrial and commercial inferno which is destroying Nell and her grandfather, and the free and pure country which is close to the divine;" an idea well expressed in George Cattermole's illustration of Nell and her grandfather looking back at London from the outskirts of the city (Dickens 2008, 123; see fig. 6). Miller (1965, 95) also argues that the novel is a "pilgrimage toward the past," a "past of barely remembered childhood, and, behind that, [...] the happy state of pre-existence before birth," whose end 


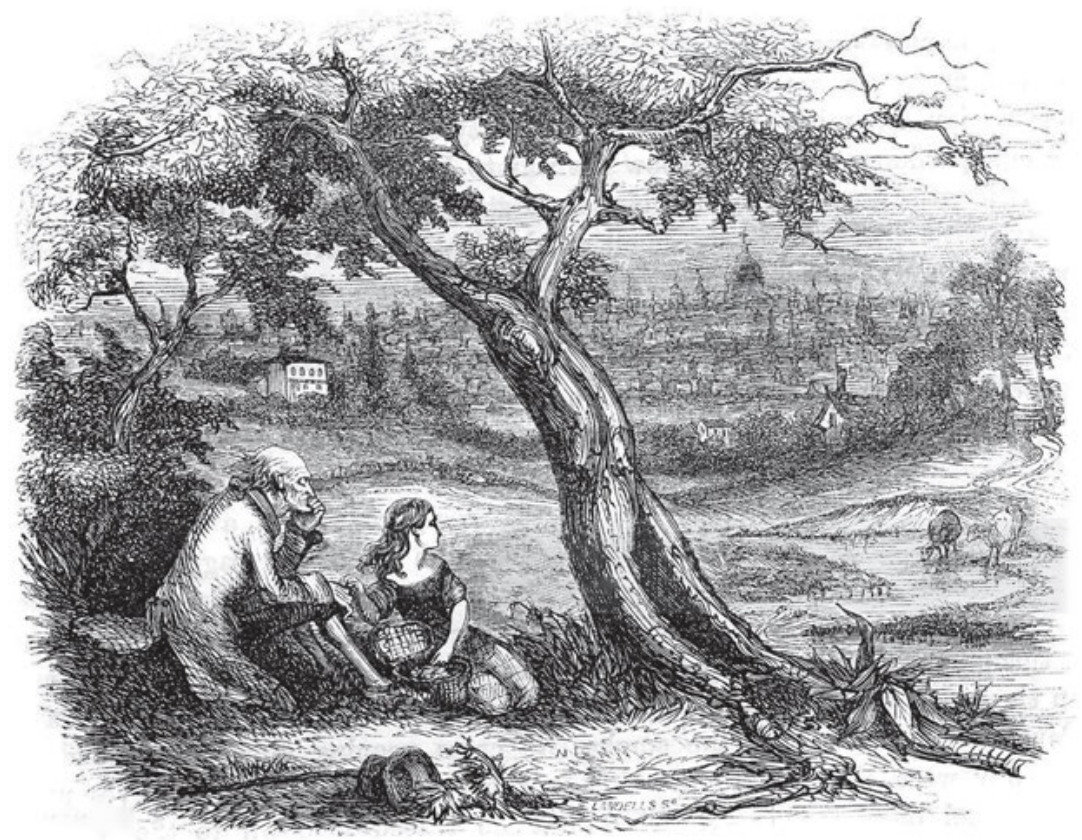

Fig. 6: George Cattermole, "Nell and the Old Man looking back at London” (1840).

is always death. In this sense, tombs (Dickens 2008, 400, 545), pits (415), ${ }^{3}$ arid places $(318,326,334,351,389,410,531)$, as well as the images of Quilp lying dead in a swamp (510) or of Nell on her deathbed (538), mark the recurrence of this idea in the visual domain. In fact, the images of Nell asleep (19) or in a faint (344) function as predictions of her death. Moreover, as mentioned by Elizabeth M. Brennan (2008, x), in the book, even people are displayed as human curiosities, which implies the loss of one's identity. Thus, in this novel, the illustrations can be seen as depicting a declining trajectory of alienation, which eventually leads to death.

Finally, in Bleak House, the illustrations represent the dualities that permeate the novel. In contrast to what happens in The Old Curiosity Shop, these dualities are not expressed by oppositions between two conflicting ideas or elements, but by the two parts forming a whole or the two sides of one and the same thing. In Bleak House, narration is assigned to two narrators, an anonymous present-tense narrator and the protagonist, Esther Summerson. This is enough to indicate the

3 "Nell and the Sexton," by Daniel Maclise. 
twofold aspect of the narrative, which combines the narrator's immediate account of the events and Esther's autobiographical retrospective; they connect present and past and display two correlated styles. Other binary associations can be traced in the novel by considering aspects of character and plot. Esther and Lady Dedlock, for example, although living in the same town, remain dead to each other in alienation from the truth about themselves - that Esther is in fact Lady Dedlock's illegitimate daughter. Esther and Lady Dedlock also, in a sense, seem to exchange roles: being a mother, Lady Dedlock fails to fulfil a maternal ideal; not being a mother, Esther has a motherly instinct which makes her take care of everyone around her and even be called by (suggestive) nicknames such as "Mother Hubbard" (Dickens 1977, 90). This gives them the dual quality of being both mothers and daughters at the same time.

These dualities are manifested visually by two distinct types of plate featured in the book, which also exemplify two styles created by Phiz: one in the "ordinary" caricatural mode, typical of the artist's works, and another, more realistic, found in the so-called dark plates, in which close lines added to the plate before the etching process is concluded (Cohen 1980,109) give the printed drawing a darker tone. Including the frontispiece, there are ten dark plates in Bleak House, of which “Tom-all-Alone's” (Dickens 1977, 552; see fig. 7) is an example. In it, not only are the cruel realities of the London slums exposed; the cold atmosphere also reflects the solitude and mysteries surrounding the characters' lives. In fact, the dark plates act as emblems of the obscurity of the characters' past, a past about which they are seeking answers, but by which they are haunted at the same time. If, in the text, the fog epitomizes "spiritual blindness" (Miller 1965, 163), the dark plates act as its counterpart in the illustrations. Evidence of this can be found in their emphasis on the environment (landscapes, empty rooms, outdoor spaces), in which the human figure, when present, can barely be distinguished. Contrarily to the dark plates, the typical plates in Bleak House (whether stressing action to a greater or lesser degree) concentrate on the characters. However, both types of plate are complementary and interdependent, in that they can be seen to represent the instances of narration conducted by the anonymous narrator and by Esther. Most commonly featured in the chapters narrated by the former, the dark plates describe states, a set of ever-present conditions which seem to be frozen in time and which are presented from the neutral (even cold) point of view of the narrator. The plates illustrating Esther's narrative, on the other hand, portray more intimate scenes (Dickens 1977, 33; see fig. 8), as (albeit also distanced by memory) Esther sees herself interacting with the other characters in her account of her past.

It is clear that the illustrations discussed here represent the text differently in each novel not only because (obviously) the books are different, deal with dis- 


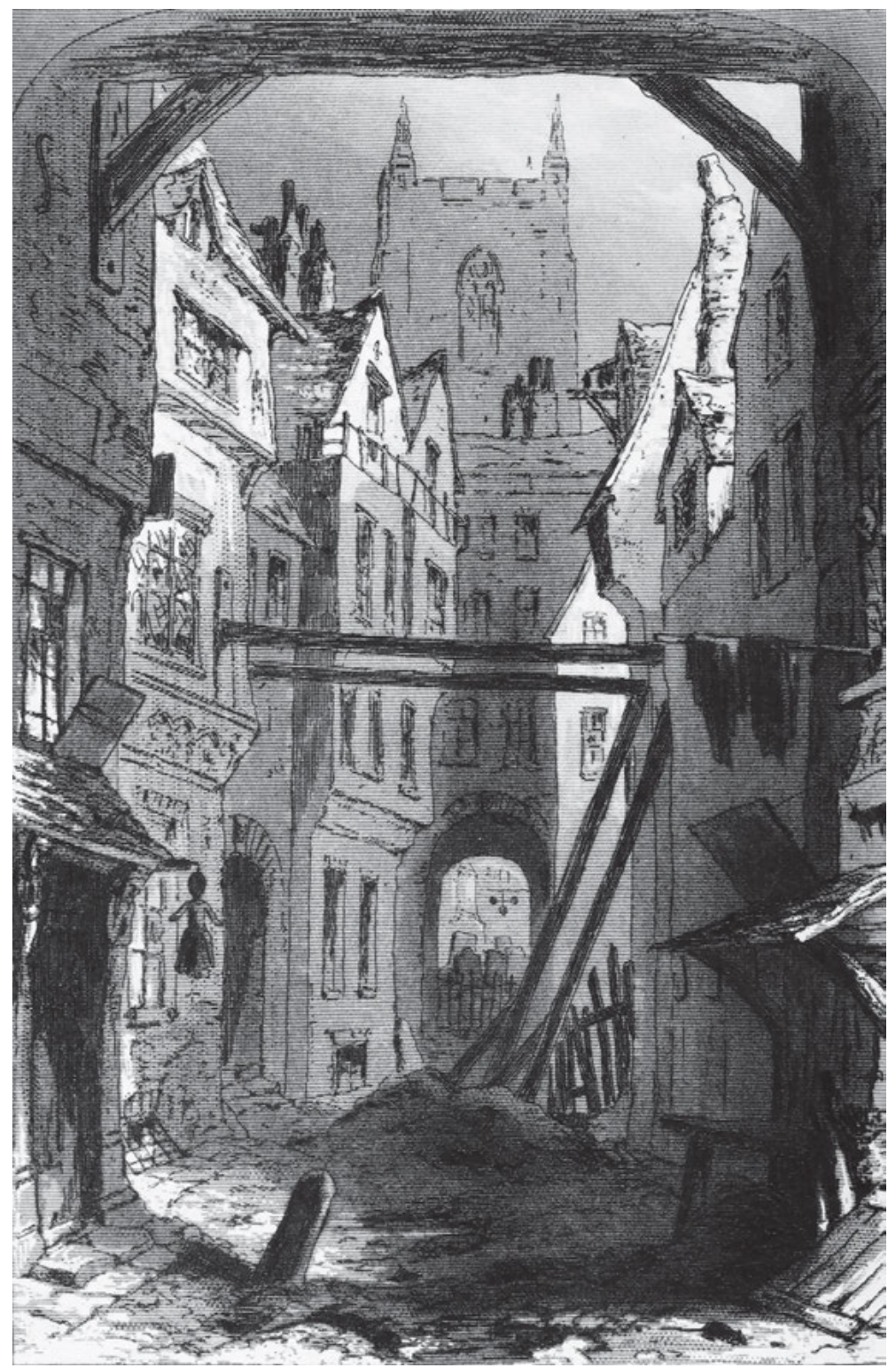

Fig. 7: Hablot Knight Browne, “Tom-all-Alone's” (1853). 


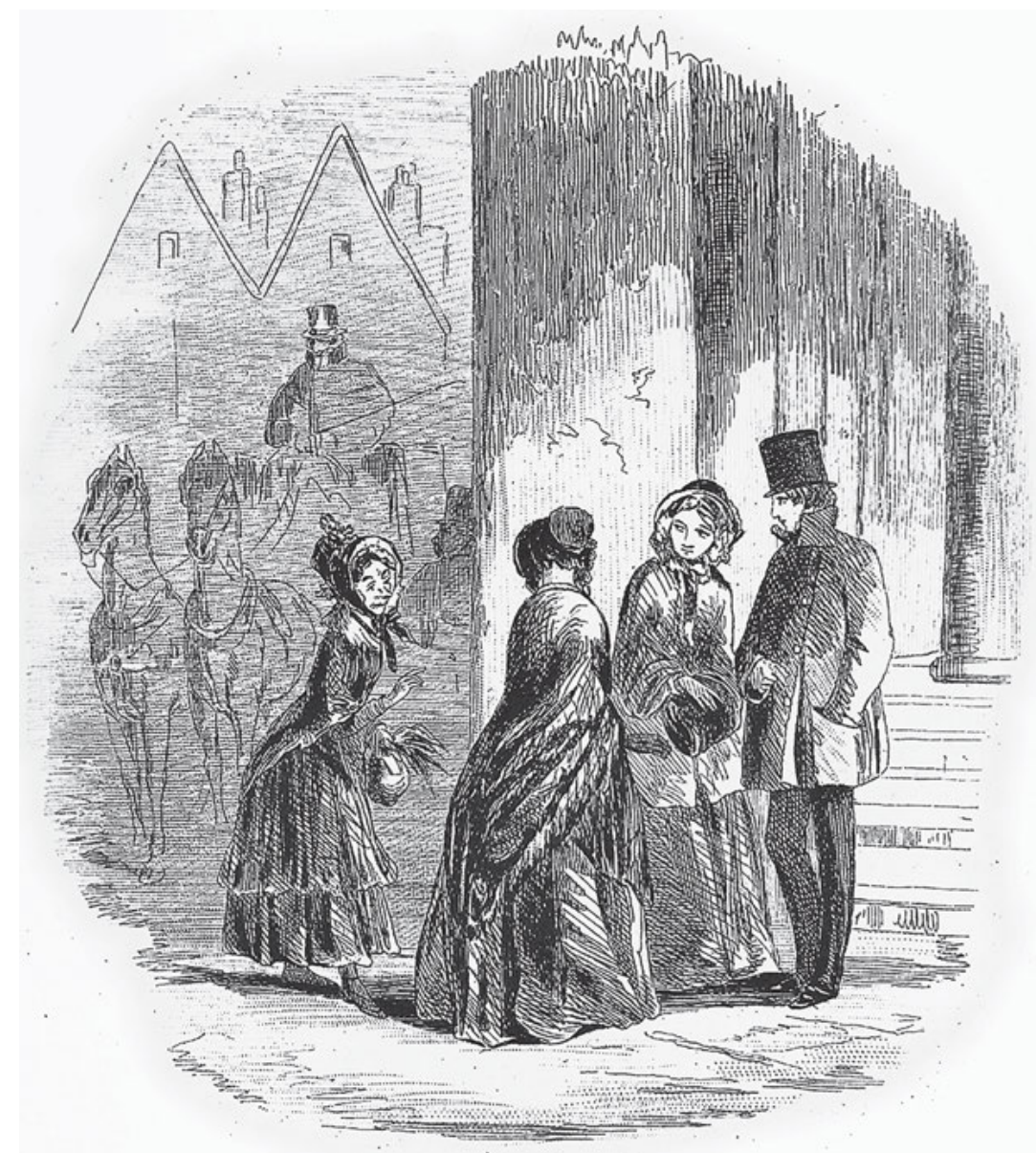

Fig. 8: Hablot Knight Browne, “The little old Lady” (1852).

tinct subjects and themes, and were written in varied contexts, but also because, by approaching the texts differently (in terms of purpose, decisions on what to illustrate, and resources at their disposal), the artists developed different types of association between the text and the pictures in each book. While this is, again, quite obvious, it allows us to determine what functions the illustrations are ascribed in the illustrated work. The function(s) the illustrations perform in a book cannot be predicted or classified in advance. In the particular cases considered here - elaborating on the discussion of the concept of illustrating and the function(s) of illustrations in a work - the illustrations can be seen to represent 
contrasting themes in The Old Curiosity Shop, the dualities of narration in Bleak House, and the ironic relationship between image and text in Oliver Twist only in the light of the circumstances under which they were produced. In every case, they can be said to evoke the text visually, for its verbal information is given form by means of lines and patterns of light and shadow - which legitimizes illustration as translation.

From the perspective of translation, illustration can be seen not as an isolated activity of crafting images for words - although pictures invariably do this - but as a process which shapes the way the literary work is received. This view also allows for the study of the various types of constraints influencing illustration and how the pictures reflect ideologies and the aesthetic attitudes and concerns of illustrators in different times. As translation, therefore, illustration establishes a parameter for how the verbal and visual narratives coexist in an illustrated book. The suggested primary function of illustration is a starting point for establishing the secondary function(s) that the illustrations may fulfil. From that point onwards, other relevant questions pertaining to translation can be applied to illustration (we can, for example, ask what counts as visual literalness or fidelity in visual representation), so that studies which examine illustrations in such a light are of paramount importance to both translation and visual studies. And there are more than enough illustrations in Dickens's works with which to do this.

\section{Works cited}

Behrendt, Stephen C. "Sibling Rivalries: Author and Artist in the Earlier Illustrated Book." Word and Image 13.1 (1997): 23-42.

Brennan, Elizabeth M. “Introduction.” The Old Curiosity Shop. By Charles Dickens. Ed. Brennan. New York: Oxford University Press, 2008. vii-xxxii.

Campos, Haroldo de. Metalinguagem. 1963. Rio de Janeiro: Vozes, 1970.

Cohen, Jane R. Charles Dickens and His Original Illustrators. Columbus: Ohio University Press, 1980.

Delisle, Jean, Hannelore Lee-Jahnke, and Monique C. Cormier, eds. Terminologie de la traduction. Amsterdam: John Benjamins, 1999.

Dickens, Charles. Bleak House. [Illus. Hablot Knight Browne.] 1852-1853. Ed. George Ford and Sylvère Monod. New York and London: Norton, 1977.

Dickens, Charles. Oliver Twist. [Illus. George Cruikshank.] 1837-1839. Ed. Philip Horne. London: Penguin, 2002.

Dickens, Charles. The Old Curiosity Shop. [Illus. George Cattermole, Hablot Knight Browne, Samuel Williams, and Daniel Maclise.] 1840-1841. Ed. Elizabeth M. Brennan. New York: Oxford University Press, 2008.

Gannon, Susan. "The Illustrator as Interpreter: N. C. Wyeth's Illustrations for the Adventure Novels of Robert Louis Stevenson.” Children's Literature 19 (1991): 90-106. 
Gill, Bob, and John Lewis. Illustration: Aspects and Directions. London: Studio Vista, 1964. Harthan, John. The History of the Illustrated Book. New York: Thames and Hudson, 1981. Hodnett, Edward. Image and Text: Studies in the Illustration of English Literature. 1982. Aldershot: Scolar Press, 1986.

Hodnett, Edward. Five Centuries of English Book Illustration. 1988. Aldershot: Scolar Press, 1990.

John, Juliet. Charles Dickens's Oliver Twist: A Sourcebook. London and New York: Routledge, 2006.

Jakobson, Roman. “On Linguistic Aspects of Translation.” 1959. The Translation Studies Reader. Ed. Lawrence Venuti. London and New York: Routledge, 2000. 113-118.

Leach, Eleanor Winsor. "Illustration as Interpretation in Brant's and Dryden's Editions of Vergil." The Early Illustrated Book: Essays in Honor of Lessing J. Rosenwald. Ed. S. Hindman. Washington: Library of Congress, 1982. 175-210.

Miller, J. Hillis. Charles Dickens: The World of his Novels. Cambridge: Harvard University Press, 1965.

Miller, J. Hillis. Illustration. London: Reaktion Books, 1992.

Nodelman, Perry. Words about Pictures: The Narrative Art of Children's Picture Books. Athens and London: The University of Georgia Press, 1988.

Oittinen, Riitta. Translating for Children. New York and London: Garland, 2000.

Pereira, Nilce M. "Book Illustration as Intersemiotic Translation: The Case of Alice in Wonderland in Brazil." Across Boundaries: International Perspectives on Translation Studies. Ed. Dorothy Kenny and Kyongjoo Ryou. Newcastle: Cambridge Scholars Publishing, 2007. 56-77.

Schwarcz, Joseph. Ways of the Illustrator: Visual Communication in Children's Literature. Chicago: American Library Association, 1982.

Tymoczko, Maria. Translation in a Postcolonial Context. Manchester: St. Jerome, 1999. Venuti, Lawrence. The Translator's Invisibility. London and New York: Routledge, 1995. Weitzmann, Kurt. Ancient Book Illumination. Cambridge: Harvard University Press, 1959.

Nilce M. Pereira is a lecturer in English Literature at the State University of São Paulo, Brazil, where she teaches at both undergraduate and graduate levels. Her primary research interests include translation and intercultural studies; Victorian literature and culture; (the translation of) children's literature, comics and graphic narratives; and the association of the verbal and the visual in illustrated publications. 
